\title{
Wheresoever the Body Is: \\ Image, Matter and Corporeality on Shakespeare's Stage
}

\section{Matthew Wagner}

Wheresoever the body is, thether will the Eagles be gathered together Luke 17:37

This passage from the Gospel of Luke served Bishop William Barlow as his central theme for a sermon delivered in the presence of Queen Elizabeth during Lent, 1601. Contextualized by a recent (and indeed, ongoing) history of vicious debates surrounding the presence or absence of the body of Christ in the sacrament, Barlow's sermon did not actually take the Eucharist as its subject, at least not directly so. In fact, he steers somewhat clear of the kind of explicit engagement with the topic that wreaked such havoc for his (near-) contemporaries, such as Thomas Cranmer. Instead, he offers a perspective on Christ's love for humanity that is heavily corporealized, delivering a sermon that insisted on a kind of material presence that sat somewhere between the literal and the metaphorical. And that 'kind' of materiality was focused on, and derived from, the body.

Barlow's source - and indeed, the bodycentred perspective it underscores - might also do apt service as an epigraph for the tenor of Shakespeare Studies in the past three decades, which have seen, as Keir Elam noted as early as 1996, a “corporeal turn” (142). Elam marked even then a "shift from a primary concern with 'language' to a primary concern with the body" (142-143). One might readily argue that such a concern has been adequately addressed, and then some: the scholarship that has tracked - and enacted - that shift has subjected the "Shakespearean body" to an expansive litany of critical treatments and tortures. ${ }^{1}$ Even a cursory look at some of the scholarship of the past few decades on Shakespeare and the body suggests a rather diverse range of interests and approaches. To paraphrase a quip by Elam, the body has been counted as tremulous, single-sexed, doublenatured, enclosed, intestinal, consumed, carnivalized, effeminized, embarrassed, sodomized, emblazoned or dissected, and disease-ridden (144). Since Elam's work, scholars have further considered the body interiorized (Hillman, 2007 and Schoenfeldt, 1999), gendered (Rutter, 2001), fragmented (Owens, 2005), temporal (Siemon, 2001), and indeterminate (Sanders, 2006). ${ }^{2}$ A common, if elementary, linkage amongst these perceptions of corporeality is that the body is first and foremost a thing: the actor's body was, in Elam's words, possessed of "an irreducible and unrationalizable materiality" (143). ${ }^{3}$ I would add to his adjectives "irrefutable" (and not merely for the alliterative pleasure afforded). Another common linkage is that each of these perspectives seems to assume this elementary issue of corporeal materiality without engaging in a detailed analysis of such materiality in and of itself. $^{4}$

Hence, quite apart from relenting, I propose here to poke and probe at the matter a little further. My primary concern is figured in the terminology I employed above: "the body," "primary," and "matter". In short, my question is: what, primarily, is the body on (Shakespeare's) stage? And my short answer, which requires 
explication in the following pages, is that the body is primarily matter, and, moreover, it is primary matter. Put another way, my argument is that a consideration of the body as matter opens up some intriguing insights about the function of the actor on Shakespeare's stage.

The first of these insights is somewhat counter-intuitive, and in fact may appear as selfcontradictory: early modern corporeality must be understood in terms of a matter-form continuum, wherein matter and form are distinct and relational to one another, but also mutually affecting.

From such an understanding arise three theses about the role of the body in Shakespearean stage craft: 1) the body is microcosmic, containing within itself the vastness of everything outside of its own fleshy confines; 2) the theatrical corpus is a primary instance of materiality, and by primary I mean both first and most important, but also immediate and generative; 3) due to its primary and unique materiality, the body on stage is transformative, both of itself and of its surroundings. Finally, I suggest in this article that two related tropes from early modern England, along with a selection of their visual representations, form a constructive paradigm in which to explore the question of the material Shakespearean body; these tropes are the alchemical notion of prima materia and the alchemical/cosmographical notion of the microcosm, and specifically of "man" as microcosm.

\section{The Eagle and the Body}

One of the very telling elements of Bishop Barlow's sermon is the way in which it highlights the subtle interplay between materiality and metaphor at work in early modern England, particularly with respect to the body. He begins by articulating a highly metaphorical reading of the lines from Luke. We might, he suggests, be tempted to interpret the Gospel's use of the term "body" in a number of contemporary, figurative ways: "the body" could be read as the English Court (a body dangerously ripe for ravaging), the Anglican Church (a body already over-ravaged), the courts of law, and even the Vatican - that corpus Catholicum that tempts sinful feasting upon "immunities to warrant sin, indulgences to remit sin, jubilees for liberty" (Barlow 4), and a host of other unwholesome and sickly morsels. But Barlow dismisses such figurative readings of Luke's use of "the body" fairly quickly, suggesting that these interpretations are only rhetorically and superficially pleasing, if at all.

A more serious reading, he proposes, is one which understands Luke's use of "the body" as a materialization of the love of Christ, nourishing humanity. His summative explication of Luke's line of verse is this: "the body is Christ, and he crucified; the eagles the elect, and they sanctified; their flocking, their affection, and that eagerly sharpened; the place, His residence, and that unlimited" (7). All abstractions are cast in a material, corporeal form, and that corporeality is insisted upon. Christ's love is real and tangible, as are the qualities that reside(d) within His physical body, and this is why the eagles flock to it and feed upon it:

Christ being the very Body and substance of those graces and vertues, which in the saints of God are but accidental qualities: for in Him dwelleth the FULNES of the GodHead BODILY, and from that FULNES we all have received grace for grace. (9) 
The body of Barlow's focus is of course different from the theatrical body; the Bishop's discourse concerns divinity, not stage craft. But the principles underscoring his depiction of corporeality are not at all dissimilar from those I will propose here for the actor's body on Shakespeare's stage. The theatrical corpus is a primary instance of materiality, and by primary I mean both first and most important, but also immediate and generative; it is, moreover, transformative, both of itself and of its surroundings; and it is, lastly, microcosmic, containing within itself, in Queen Gertrude's phrase, "all that is" - the vastness of everything outside of its own fleshy confines.

We are, however, faced with an immediate complication as soon as we say that the body is matter: as the work of Butler, and even Maus, demonstrates, the body cannot easily be thought of a solely or simply matter. ${ }^{5}$ Such writers have convincingly demonstrated that the body has its own kind of subjectivity, and that any suggestion that the body merely houses consciousness, soul, spirit would be a gross oversimplification. Moreover, especially from an early modern perspective, matter itself had a very complex relationship to form, soul, spirit. In talking of the body-as-matter, then, my goal is not to strictly and surgically separate matter from form, body from mind, unthinking corporeal object from perceiving subjective consciousness; rather, by calling the body "matter," I want to place the acting body in a similar order of complex relationships to form, subjectivity, and spirit; indeed, this is precisely where the tropes of the microcosm and prima materia come into play, and Prince Hamlet offers us an excellent introduction to both.

\section{This Quintessence of Dust}

In the context of denigrating the literally mundane, earthly aspects of life, Hamlet famously calls the body a "quintessence of dust" (II.ii.274). His use of the phrase may, on the surface, be dismissive ("And yet to me what is this quintessence of dust? Man delights not me"), but, as a number of editors have pointed out, the phrase bears alchemical and cosmographical significance as well, particularly in the use of the word "quintessence". The body is nothing but dust - base matter, not worthy of anything - but it is also composed of the same stuff as the heavens; this is what the word quintessence refers to, as Thomson and Taylor suggest in the Arden edition of the play: "quintessence means 'concentration', literally, the 'fifth essence', the substance of which heavenly bodies were thought to be composed, and which, according to alchemy, could be extracted from earthly elements by a process of distillation". (257 fn274). Here is the body understood very pointedly as "just matter" - a temporary concentration of particles of dust - but simultaneously positioned as heavenly, as extramundane. In four words, Hamlet offers up the heart of alchemical thinking, and, without using the actual phrase, brings into play the concept of prima materia: the more common term for "quintessence".

Prima materia (sometimes "Materia Prima") literally translates to "first matter," but the concept actually was considerably more fluid and indeterminate, while remaining central to the alchemical process and philosophy. As "first matter," prima materia is irreducible and also generative - it is that to which base matter could be reduced, and from which higher matter could be crafted. In the simplest of terms, it was the necessary ingredient for the alchemical crafting 
of the philosopher's stone and the elixir of life (or, depending on one's source of information, it was the elixir of life itself). Such is the materiality of the Shakespearean body: it is a "first matter" which forms the basis and example for all other material presence in the (largely imaginative or immaterial) stage world of the play. ${ }^{6}$ And as we shall see shortly, equating the human body with prima material is not merely a fanciful comparison; by many accounts, prima materia was directly aligned with human corporeality.

That said, prima materia, like most things alchemical, is a notoriously difficult notion to pin down. And my gloss on the term here - which highlights the literal denotation of "the first matter," and underscores the sense matter out of which other matter develops - is not precisely what the $16^{\text {th }}$ and $17^{\text {th }}$ century alchemists meant by the term. Indeed, from the early modern perspective, it would be a mistake to speak of a precise meaning for the phrase at all. Martin Ruland's 1612 Lexicon Alchemiae, for example, identifies the Materia Prima with fifty wildly divergent things, ranging from "Lead" to "Honey", from "Shade" to "Dung", from "Sulphur of Nature" to "the Soul and Heaven of the elements" (220222). Ruland, in fact, explicitly acknowledges the undefinable nature of the Materia Prima:

The philosophers have so greatly admired the Creature of God which is called the Primal Matter, especially concerning its efficacy and mystery, that they have given to it many names, and almost every possible description, for they have not known how to sufficiently praise it. (220)

Ruland's list and description are notable for a few reasons: first, his list contains both items that we would think of as the epitome of earthly matter (lead or dung) as well as "items" that might epitomize all that is non-earthly, above the realm of mortality (the soul of heaven and the elements). Secondly, the indeterminacy of prima materia is highly significant, in that it accounts for the malleable and transformational qualities of this "first matter": prima materia is always in flux, and as such, might become anything. Moreover, it might facilitate other matter to become something else. Prima materia, in this respect, is matter that is transformational and generative, capable of altering itself or the material reality around it. And here we begin to see why the concept offers a useful lens for, and has a direct link to, the theatre and the actor's body in particular: a body which perhaps more so than any other kind of body or matter transforms both itself and its surroundings. To see the body in the framework of prima materia is to understand it as a very specific kind of matter not simple, dead earth as it were, not mere dust, but a quintessence of dust. It is a concentration of the elements of the cosmos. And on stage, this quintessence of dust, this body-as-matter, is capable of transforming itself, and its surroundings, and of calling forth other material presences. This kind of material body "lends" its materiality to the stage, thereby allowing all the immaterialities - spirits, abstractions, and otherwise "absent" ideas or concerns - that the stage so regularly "bodied forth" to be materially present. ${ }^{7}$

\section{Homo Microcosmos}

The third way in which Martin Ruland's description of prima materia is instructive is the fact that he aligns prima materia with the notion of the microcosm. The first and the fiftieth of his list of names for this first matter are the same: he calls the Materia Prima a "Microcosmos," saying 


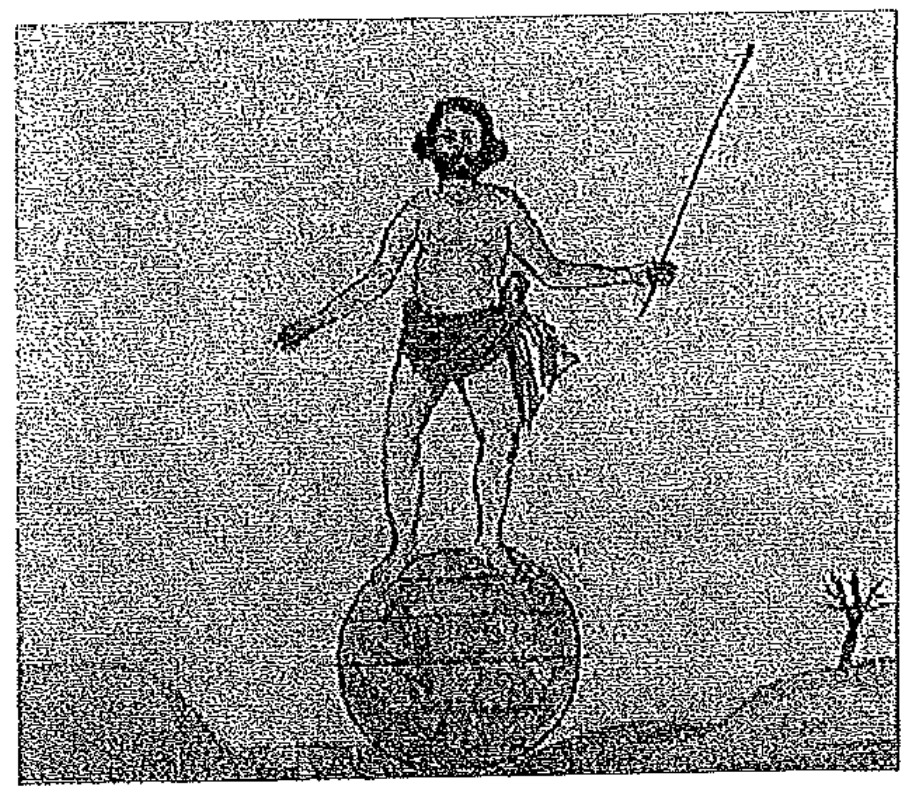

\section{Figure 1}

Henry Peacham, "Man the Microcosm," c. 1610. In Alan Young, Henry Peacham's Manuscript Emblem Books. University of Toronto Press, 1998.

first that "1. [the philosophers] originally call[ed] it Microcosmos, a small world, wherein heaven, earth, fire, water, and all elements exist, also birth, sickness, death, and dissolution, the creation, resurrection, etc." (220). His list then ends where it began: "50. Microcosmos because it is a likeness of the great world, through heaven, the sea, and all the elements" (223).

So, alchemically, prima materia is defined (in part) as a microcosm; and it will probably be no great revelation to say that early modern cosmography frequently thought in terms of macrocosm and microcosm, and that both the theatre itself and the human body figured prominently in this thinking: both stage and corpus were microcosmic versions of the whole of existence. ${ }^{8}$ Shakespeare provides some obvious theatrical examples with respect to seeing the body as the world: the "finding out of countries" on the body of Nell the kitchen maid in Comedy of Errors, for instance (III.ii.113-137), or
"Sweet Jack Falstaff" counting himself as all the world ("Banish plump Jack, and banish all the world" (II.v.438)). If the former example is somewhat light and literal, the latter carries its sense of the body as the whole world throughout much of the play. Jack Falstaff is, of course, a bit of everything, larger than life, and unable to be contained by it; and his own quip about being "all the world" is echoed, somewhat more crudely, by Bardolph later: "Why you are so fat, Sir John, that you must needs be out of all compass, out of all reasonable compass, Sir John" (III.iii18-19).

Beyond the stage, we certainly find this microcosmic perspective prevalent in the visual culture of the day. Two strong examples exist in the work of the popular emblematist, Henry Peacham (Figures 1 and 2); the first dates from 


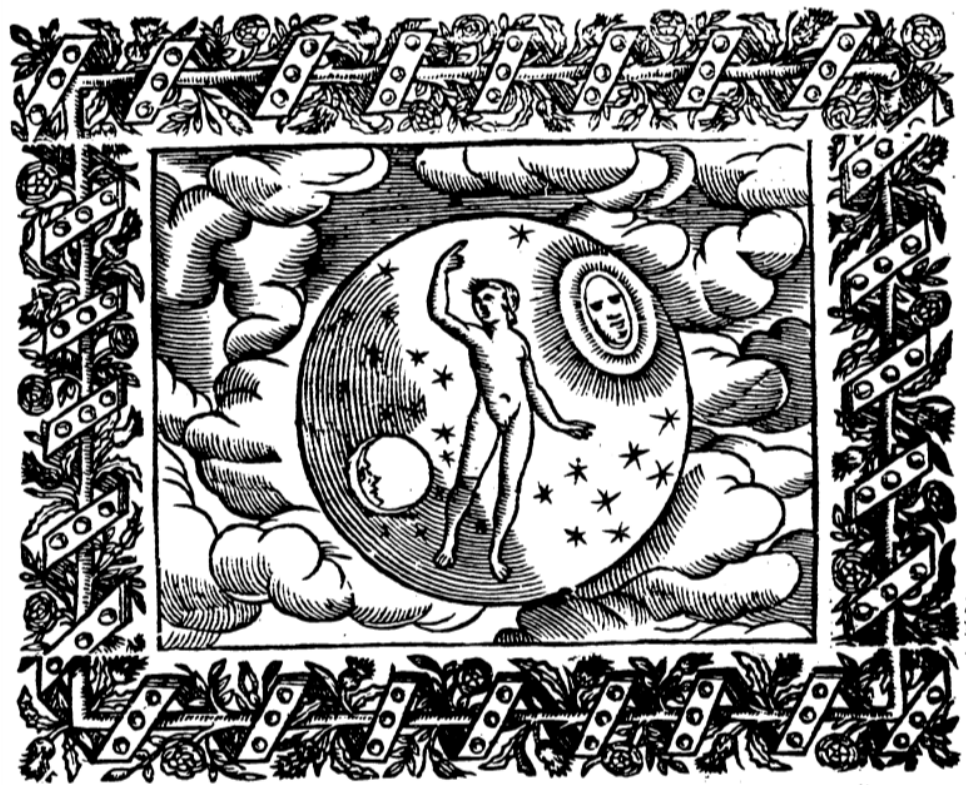

T EARE what's the reafon why a man we call

1 A little world? and what the wifer ment

By this new name? two lights Coleftiall

Are in his head, as in the Elcment:

Eke as the wearied Sunne at night is fpent, So feemeth but the life of man a day, At morne hce's borne, at night he flits away.

Of heate and cold as is the Aire compoicd, So likewife man we fec breath's whot and cold, His bodie's earthy : in his lunges inclofed, Remaines the Aire : his braine doth moifture hold, His heart and liver, doe the heate infold: Of Earth, Fire, Water, Man thus framed is, Of Elcments the threcfold Qualities.

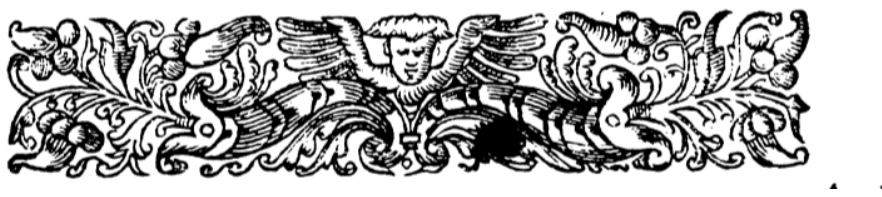

Figure 2 Henry Peacham Homo Microcosmus. Minerva Britanna, London 1612.

around 1610, and is in an unpublished manuscript, edited here by Alan Young, that predates Peacham's more widely known Minerva Britanna of 1612, the source of the second image. Both depict "man" as a microcosm, but in clearly divergent fashions.

In the earlier of the two emblems (Figure 1), we see a pseudo-realistic depiction of a human being; clearly, the epigram identifies this figure as "man, the microcosm," but visually, it is the position of the body both on and in the world that seems significant. The physical being is at once that which exists, here before us, in cohesive and tangible fashion, but also that which is beyond us, straddling the world, and with the power (as indicated by the wand and the reference to the 


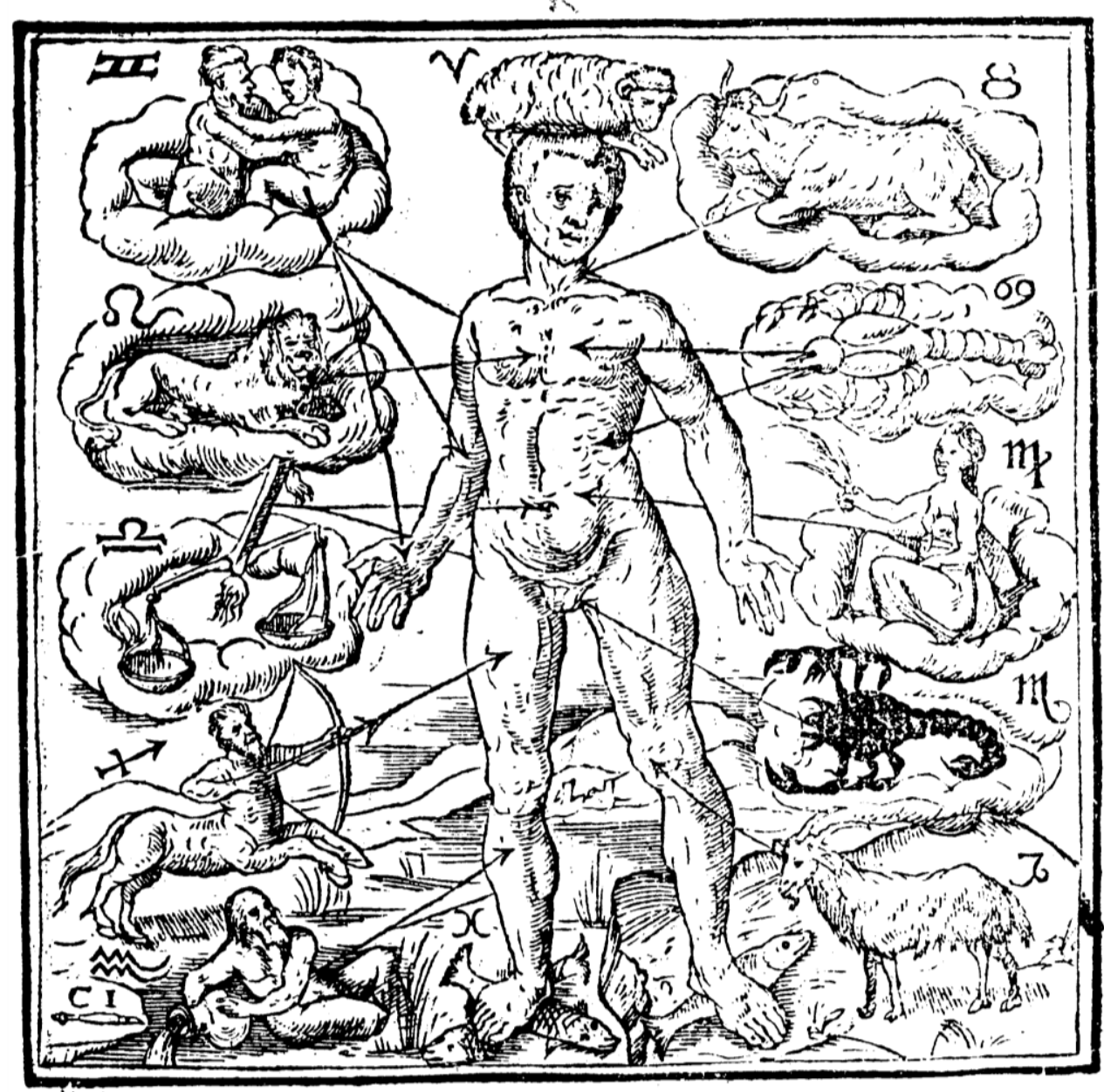

Figure 3 Leonard Digges, A Prognostication Everlasting (Frontispiece). London 1576.

"divine sparks") to both affect and supersede the world. ${ }^{9}$ The human form here is the manifestation of all that is. In the second, slightly later emblem, the human form is less realistically (and more allegorically) rendered. It shares a sphere of existence with celestial bodies, and, as the verse indicates, it also materially echoes those celestial bodies, with "two lights Celestailll [...] in his head" (Peacham 1612,190), and so on. The verse attributes the things of heaven to the physical form of "man," very notably focusing on the material form of the body - eyes, breath, lungs, brain, the humoral governance of physicality, and even the span of mortal life itself. In so doing, the emblem inscribes the heavens onto the body; but clearly, the inverse is also true here - the body is literally inscribed onto the world, just as the sun and moon are. The conjoined presence of the sun and moon, moreover, is the "simplest cryptogram for representing time in the abstract," as S.K. Heninger puts it (3). ${ }^{10}$ The physical form of the human being is at once in the cosmos, of the cosmos, and manifesting the cosmos, including those aspects of creation, like time, that might 


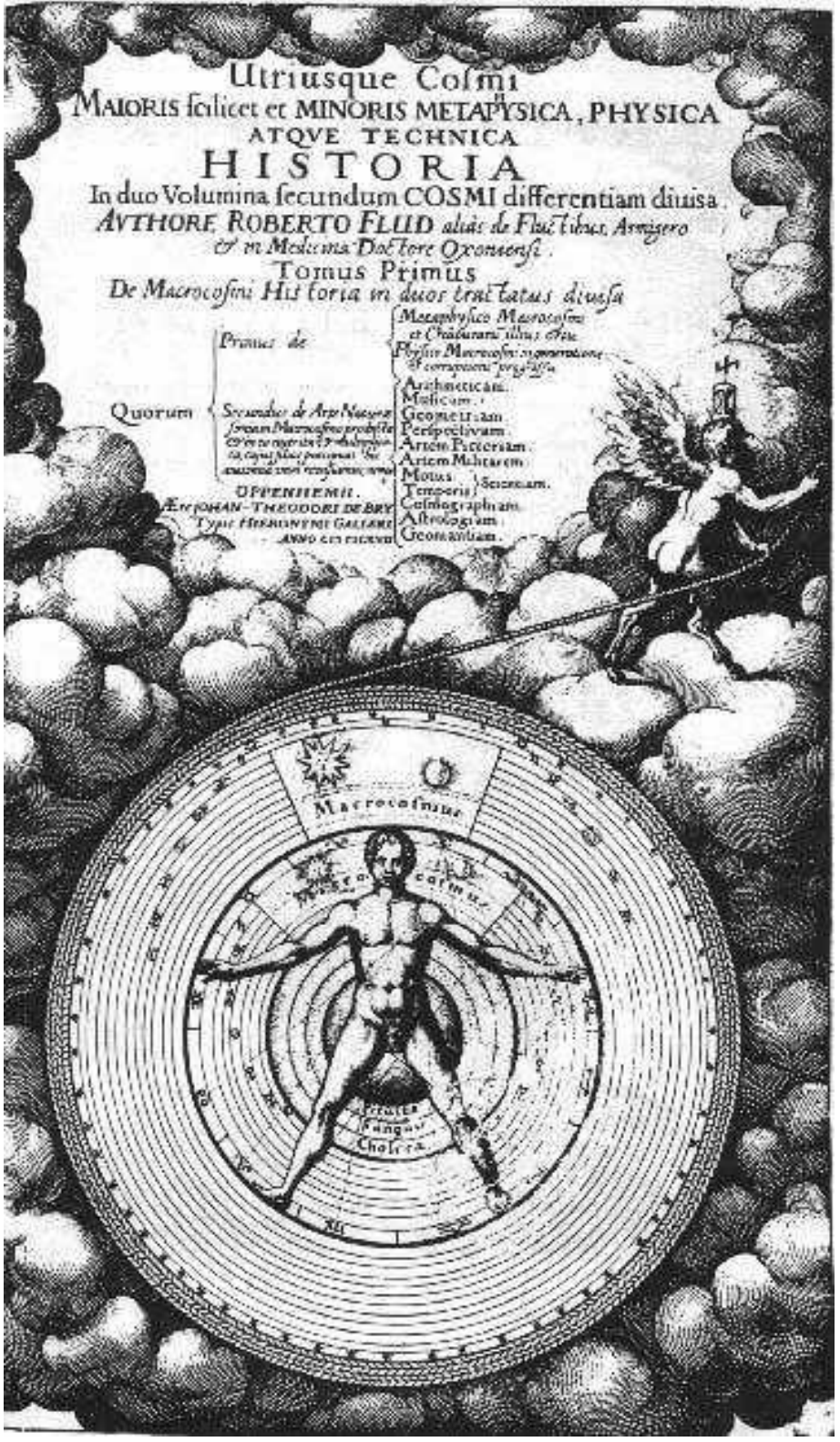

Figure 4

Robert Fludd, Utriusque ... Cosmi Historia

(Frontispiece). Oppenheim, 1617.

otherwise seem resolutely immaterial and unmanifestable.

Peacham's second emblem dovetails nicely with a very common visual depiction of the body (of which the next image is representative), which saw the cosmos mapped onto the human form by way of assigning zodiacal signs to different parts of the body (Figure 3).
Again, it is no new news that a prevalent early modern view of medicine figured the body as governed (at least in part) by astrology; what is germane here is that such a view partakes heavily in the microcosmmacrocosm picture of the universe that counted the body as the materially present form of the intangible, immaterial realities of existence. In Peacham's Homo Microcosmos, the body is part and parcel of the cosmos; in Digges' frontispiece (and in the variety of other images like it), the cosmos is part and parcel of the body. The distant and abstract attributes of the planets and stars found very real and material expression in the workings of the body. ${ }^{11}$ What was true of astrological abstractions was also true theologically; in 1576, John Woolton, Bishop of Exeter, penned $A$ New Anatomie of Whole man, as well of his body, as of his Soule. In his Epistle Dedicatory, Woolton insists on the study of anatomy as a key to understanding the whole man, particularly as "the inspection of Anatomie [...] deduceth the creature, to some knowledge of his Creator" (2). Where it was conventional, of course, to attribute the divine portion of humanity to the soul, we also find those sparks of divinity manifest in this "first matter," the body.

This figuring of "man" as microcosm is rendered more complexly, and with greater attention to the materiality of the body, when we return to the milieu of alchemy. Though it postdates Shakespeare's life, Robert Fludd's 1617 


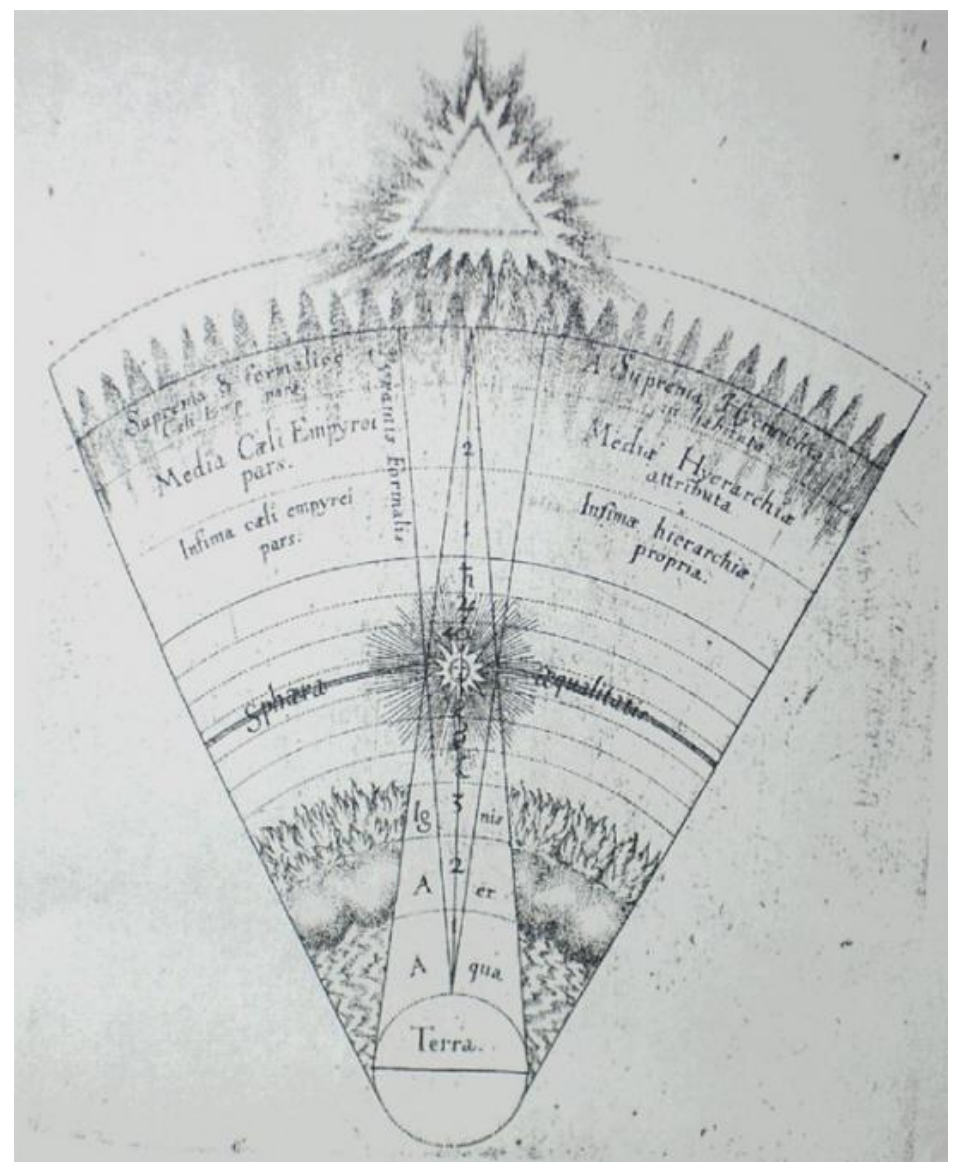

\section{Figure 5}

Robert Fludd, “De Musica Mundana”. Oppenheim, 1617.

Utriusque ... Cosmi Historia has long served as a benchmark of Elizabethan and Jacobean alchemical thinking. The first book of Fludd's volume is dedicated to an explication of the workings of the macrocosm, and the frontispiece signals that (Figure 4). Here is the human body positioned precisely in terms of a microcosmic manifestation of the macrocosm. Again, the zodiac criss-crosses the body, and the central, earthen sphere is surrounded by three spheres of water, air and fire, which correspond to anatomical attributes. That which exists "out there" has a direct and tangible corollary - a material reality - "right here". And the body is, in this figure, clearly the "first matter" - it is primary, central, and the most significant form of matter in this kind of cosmography.
Indeed, as Heninger suggests, this kind of cosmography understood the universe as a continuum of matter and form, to borrow the Platonic terms. He notes that "Formality' and 'materiality' are different orders of existence" (28), but, crucially, those different orders are overlapping and mutually conversant. Fludd depicted this in a series of diagrams (Figures 57) which, especially when taken together, count the human body as a unique kind of matter. ${ }^{12}$

In the first diagram (Figure 5), Fludd crafts a picture of existence that places God at the "formal" end of a spectrum and earth (notably not man) at the material end of that spectrum. As formality increases, one gets closer to God, and vice versa. Other regular features of such cosmography are present here: spheres of water, 


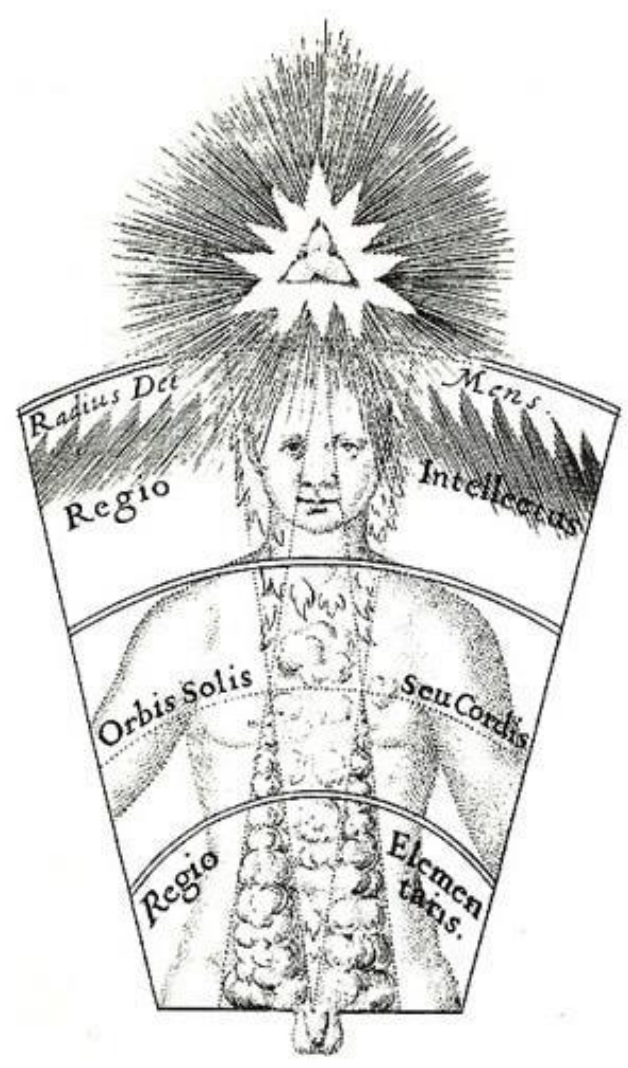

Figure 6

Robert Fludd. Oppenheim, 1617.

air, and fire; zodiacal correspondences; a precise order and structure to the universe. Noteworthy is the sphere of equality, the middle point of the spectrum, where the realms of matter and form are in perfect equilibrium; this is the sphere of the sun. Heninger's explication is this: "Here formality and materiality are in exact balance; the Sun has a component to be perceived by the intellect which is exactly equivalent to its component to be perceived by the senses" (29). The sun is matter and form all at once. Turning to the next two images (Figures 6-7), we see versions of this diagram superimposed onto a human body, and this median sphere of equilibrium, termed now "Orbis Solis" and "Via Solis," becomes the realm of the human heart: the centre and core of a human being and, more precisely, a human body.
Once again, the body is in, around, and representative of the cosmos; and just as the universe has a centre, the sun, that is equal parts matter and form, so the homo microcosmos has its corresponding centre, the heart, which similarly presents itself in equal measure to the perception of senses and intellect. It is not hard to imagine that a similar division - separating that which answers to the senses from that which answers to the intellect - is precisely what Hamlet has in mind in his comments about Gertrude's cleft-intwain heart:

QUEEN: 0 Hamlet, thou hast cleft my heart in twain.

HAMLET: 0 throw away the worser part of it

And live the purer with the other half. (III.iv.154-156)

The "worser" part, to Hamlet, would surely be that which corresponds to matter, and responds to the material world of flesh: a heart (or portion thereof) that resides "in the rank sweat of an enseaméd bed, / Stewed in corruption", or one that can be swayed and fulfilled by allowing the "bloat king [to] pinch wanton on your cheek" (III.iv.82-83; 166-167).

Indeed, one might argue that the whole of Hamlet is an exercise in exploring that relationship between the "sensible" and the "cognitive," particularly with respect to the material body and the way in which that body is, to come back around to the Prince's term, a "quintessence of dust": at once base matter and the stuff of the heavens. ${ }^{13}$ Hamlet spends much of the play insisting on the separation of body (base matter) and mind (ideal form, a higher mode of existence), and of course denigrating the former while purporting to idealize the latter. 


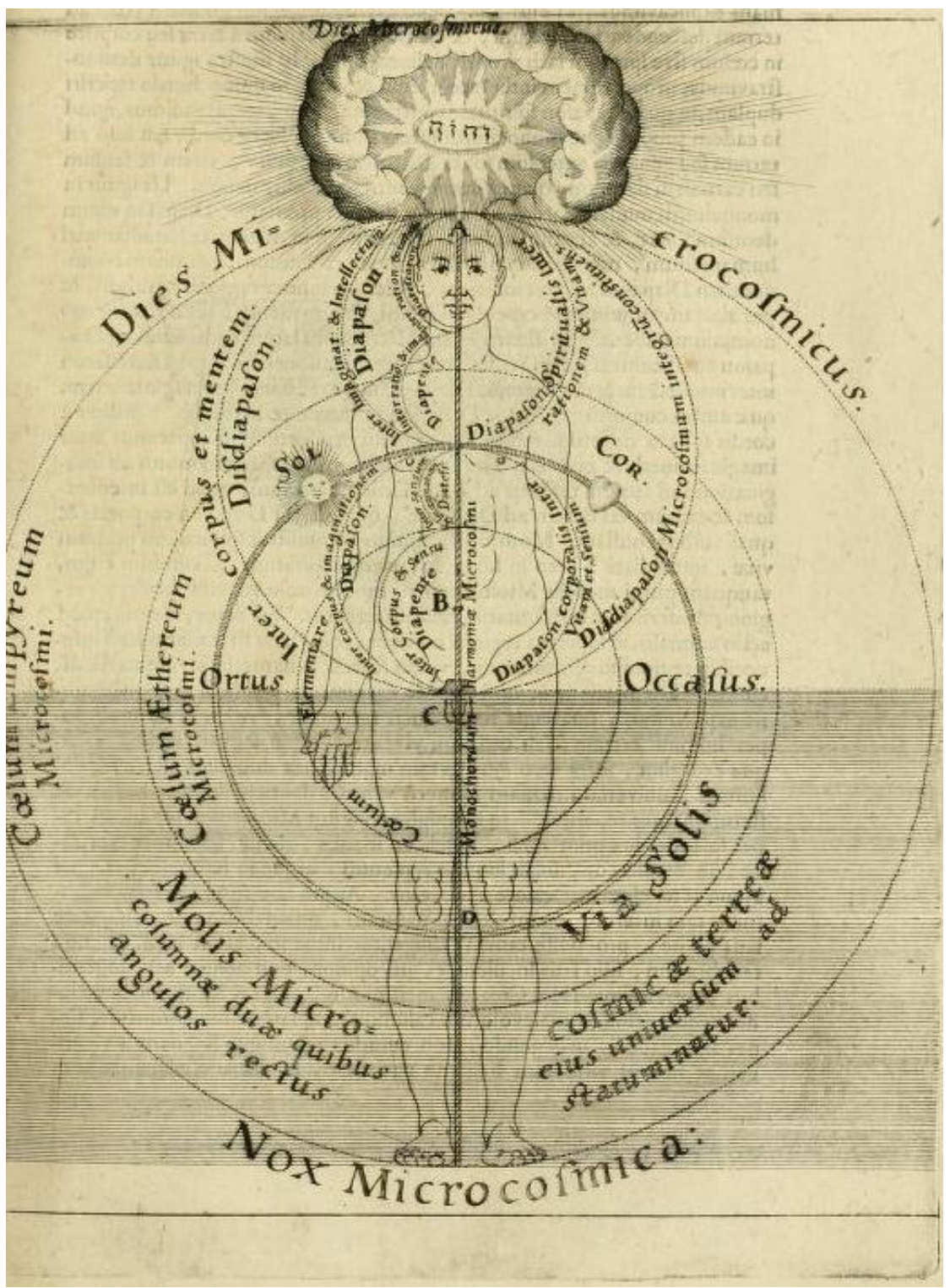

Figure 7 Robert Fludd. Oppenheim, 1617.

This insistence, though, is fraught from the beginning of the play. For instance, as Hamlet reels from his encounter with the Ghost, and vows to honour the latter's parting words, "remember me" (I.v.91), he at once inscribes the hierarchy of form over matter while simultaneously depending heavily on giving a material quality to an immaterial reality such as memory:

\section{Remember thee!}

Yea, from the table of my memory

I'll wipe away all trivial fond records,

All saws of books, all forms, all pressures past,

That youth and observation copied there, And thy commandment shall alone live Within the book and volume of my brain, Unmix'd with baser matter.

(I.v.96-104) 
On the surface, Hamlet's monologue expresses a simple determination to focus his thoughts and energies on nothing but avenging his father, the comparative adjective "baser" signifying that anything less important than this task will be eradicated from Hamlet's brain. But this specific vocabulary calls forth a comparison between matter and form, wherein all things connected with "baser matter" are to be expunged from the loftier, aspirational realm of Hamlet's thoughts. In this respect, the term "baser matter" foregrounds that distinction between spirit and flesh, mind and body, and it iterates Hamlet's hierarchical positioning of the two. In the same breath, however, the passage figures memory in the highly physicalized form of tables, books, and pressures, and indeed it does the same for the brain itself. It is, moreover, significant that he speaks of his brain - and not his mind, as he and others do elsewhere - leaning toward the physiological item, the corporeal organ itself, rather than the ungraspable consciousness of a perceiving subject. In other words, as we look beyond the surface meaning of the lines and into the connotative resonances of the vocabulary, we see Hamlet setting himself the seemingly impossible task of expelling baser matter from what is itself baser matter. As such, the separation between body and mind that Hamlet so frequently articulates, and the aspiration to the leave the former behind and dwell in the realms of the latter, are both significantly undercut. And in place of such separation, the play in fact presents (perhaps against Hamlet's will, as it were) a picture of the relationship between matter and form that is much closer to that described by Fludd's diagrams: a continuum, rather than a division of realms.

For all of his wit, then, Hamlet the character seems to miss a trick here, one which the play more broadly picks up. That the body was, as Hamlet casts it, "baser matter" did not necessarily mean that it was to be dismissed as such - thrown down in disgust as Hamlet eventually does with Yorick's skull - nor that it was separable entirely from the spirit. For Bishop Barlow, the fleshiness of the body was responsible for the availability of divine love; in similar, but broader, terms, materiality itself was responsible for the availability of all that would otherwise remain out of reach. If, in other words, there is more in heaven and earth than is dreamt of in Horatio's philosophy, matter is the means by which we access and make present whatever that "more" might be. Perhaps the most obvious instance of this phenomenon in Hamlet comes in the form of the Ghost, a literally embodied and material stage presence whose very function is to allow an immaterial spirit to become manifest before the audience.

Of course, the Ghost in Hamlet, and theatrical ghosts more generally, present a far more complex set of problems when it comes to corporeality, materiality, and immateriality, and as such, the phenomenon of the theatrical ghost warrants at least some attention here. For Alice Rayner, a ghost offers a nearly perfect prism through which to view and understand the theatrical phenomena of repetition and return the ghost is that which implies reiteration, a coming back from elsewhere, a repeating of an already-accomplished presence. She also highlights the way in which the ghost foregrounds issues of illusion and reality, materiality and abstraction. "Ghosts", Rayner argues, "animate our connections to the dead, producing a visible, material, and affective relationship to the abstract terms of time and repetition" (Rayner 2006b, 13). 
It is Rayner's engagement with the coexistence of the material and the abstract that is of interest here. In Hamlet especially, the Ghost is not only a return, it is one that carries with it in its wake that which exists elsewhere - not only the dead and absent father/king, but also a separate realm (purgatory), separate times (both past and future), and forbidden knowledge. It brings forth these absent abstractions by dint of the fact that the Ghost of Old Hamlet, ontologically, is a body, full and immediate in its material presence. But it is also an immateriality, an absence, a piece of "airy nothing," to quote Shakespeare's Theseus. ${ }^{14}$ And as its immaterial components cling to, and find "local habitation and a name" in, the material body of the actor, so too the traces of its immaterial "elsewhere" cling to and find a home on the stage.

In the context of a theatrical encounter, both aspects of the Ghost exist in equal measure. One might be inclined, for example, in the closet scene to think that Gertrude is simply wrong with respect to the fact that she denies the presence of Ghost; it is tempting, here, to simply and instinctively side with Hamlet, and to insist that the Ghost is in fact there. But Gertrude's perspective is every bit as valuable to and necessary for the dramatic potency of the scene as Hamlet's: theatrically, the Ghost needs to be both of flesh and of the air. And the theatrical effectiveness of the Ghost depends precisely on the fact that it straddles these two spheres of materiality and immateriality, allowing the body of the actor to be both at once. The phenomenon is reminiscent of Helkiah Crooke's litany of the classical commentary on man as microcosm (see fn 8), and especially of his citation of Sinesius, who calls man "the horizon of corporeal and incorporeal things" (Crooke 3). In this respect, the Ghost in Hamlet allows us to see the actor's body in its material fullness precisely because the stage presence of the Ghost simultaneously highlights the opposite: an immateriality. As we engage with character and fiction (the immaterial, the "spirit"), we necessarily ground ourselves in performer and "reality" (the material, the body of the actor).

As such, the Ghost underscores the two key themes that have been central in this study of the body-as-matter - the convergent relationship between matter and form, and the way in which the material body operated as a microcosm of the whole of existence. Indeed, though he may otherwise seem to miss the point, the bulk of Hamlet's speech on "the quintessence of dust" is an excellent articulation of this body-asmicrocosm motif:

[...] and indeed it goes so heavily with my disposition, that this goodly frame, the earth, seems to me a sterile promontory; this most excellent canopy the air, look you, this brave o'erhanging firmament, this majestical roof fretted with golden fire, why it appeareth nothing to me but a foul and pestilent congregation of vapours. What a piece of work is a man, how noble in reason, how infinite in faculties, in form and moving how express and admirable, in action how like an angel, in apprehension, how like a god - the beauty of the world, the paragon of animals! And yet to me what is this quintessence of dust? (II.ii.297-308)

As with Barlow's sermon, the structure and movement of this highly meta-theatrical speech is as telling as its content. Hamlet begins by drawing attention to the microcosmic function of the theatre itself: as has long been noted, the site- 
specific references (this goodly frame, this most excellent canopy, this majestical roof fretted with golden fire) facilitate a potent layering of locus and platea, to use Robert Weimann's terms. ${ }^{15}$ Placed before an audience is both Hamlet's open sky (in Elsinore) and its own (in Southwark); the frame of the Globe Theatre, to which Hamlet alludes rhetorically (and perhaps gesturally) in the speech, is at once itself and "the earth". From there, Hamlet's speech moves in, by concentric circles as it were, to map "man" in the same way: the movement is from "this goodly frame the earth," which presences Globe Theatre, Elsinore, and the whole world, to "what a piece of work is man," which similarly corporealizes actor, character, and all of mankind. And much, if not all, of Creation is figured in that mapping: infinite faculties, angelic and even divine likeness, the "beauty of the world" (language which is very evocative of that used outside of the theatre, cited earlier, specifically Crooke and Peacham). Like the stage, the body in its material presence was the localized manifestation of the whole of the cosmos. "The body is with the king, but the king is not with the body" (IV.ii.25-26) - another of Hamlet's indeterminable quips, but given this microcosmic view of the body I am foregrounding, the line takes on the meaning and weight of Hamlet's earlier "The time is out of joint" (I.v.189) or Marcellus' "Something's rotten in the state of Denmark" (I.iv.67). When the physical body, especially that of the king, is not fulfilling its microcosmic function, something is indeed wrong with the world, the universe, with time itself.

In this way, we return to issue of balance represented in Fludd's diagrams. Tragedy is a state of imbalance, a condition when the sun is not in its proper sphere, occupying (and maintaining) a state of natural equilibrium.
Indeed, we might well argue that one of Hamlet's tragic flaws is his desire to be closer to the formal end of these diagrams than the material end: his division of body and mind, matter and form, contributes to the world being imbalanced, rotten, out of joint.

But this is the precarious position of "man" in such a worldview. If one of the privileges and pleasures of the position of the heart/sun is that while there, one may be closer to a formal idea, closer to God, then its corresponding and equivalent danger is that one may fall into the lowly, sinful clutches of the world of matter. Fludd's visual depiction of the human condition suggests as much - his images relay a sense of movement (rather than stasis). The dual pyramids in Figures 5 and 6, for example, operate on the principle of increase or decrease; the eye/consciousness of the viewer is carried along the slope of the pyramid in one direction or the other. Similarly, the concentric circles of Figure 7 suggest a kind of planetary orbit. As such, the visual effect of the image is again the implication of motion: the icons of the sun and heart appear to be mobile along the "Via Solis," promising to dip into the lower, shaded realms of existence and (hopefully) to rise again. By definition, where one sees equilibrium (as in the geometric diamond created in Figures 5 and 6 by the meeting of the two pyramids), one also sees the potential for imbalance. Put another way, it is in the nature of balance that one might fall; or, it is in the nature of the sun to sometimes hide behind the clouds, or in the depths of night.

\section{Too much i'th'sun.}

As we are seeing, the identification of the sun as a site of balance between matter and form, the mundane and the divine, finds considerable expression in Shakespeare's stage craft. In 
addition to the examples rehearsed above, one thinks immediately of Hamlet's second line “Not so, my lord, I am too much i'th'sun" (I.ii.67) - or that of Richard of Gloucester in Richard III, speaking of "this son of York" (I.i.2). ${ }^{16}$ There is, of course, ample punning on son/sun in Shakespeare where royalty is concerned, drawing attention to the fact that royalty is another site of balance between the mundane and the divine. The neatest example perhaps comes with Prince Hal, who stands as something of a paragon of transformational, indeterminate matter. "Yet herein will I imitate the sun," Hal informs us (I.ii.175): this is not merely a sharing with the audience of his plans, or a statement of social status. The sun does of course represent Hal's royalty, and the foreknowledge that he will not only be king, but will be kingly, and not only kingly, but the epitome of kingliness; but, more richly, Hal's self-identification with the sun places him squarely in that median sphere between Heaven and Earth, very like Claudius (setting aside issues of being a usurper) or Hamlet (setting aside issues of being usurped). And 1 Henry IV is nothing if not a charting of the alchemical transformation of this "sun/son" from base matter to the highest form possible in the mortal world. That process follows the path of reducing Hal to the most elemental matter - to the point of irreducibility - before then reconstituting him as something better. $\mathrm{He}$ moves, literally and bodily, through the lower spheres of existence, nearly dissolving in the reconciliation scene with his father (III.ii), before rising up to conquer Hotspur and reside in the higher spheres of human life. Hal both contains and is the sun, and he contains and is the prima materia, and the stage facilitates his reduction to that pure state and his reconstitution as holy, royal, immortal.
Like Hal's promise to imitate the sun, Hamlet's barb that he is "too much i'th'sun" is, of course, richly layered. This thinly veiled verbal assault on Claudius - that Hamlet is too much in his uncle's presence - provides only slightly more substantial cover for an assault on Gertrude: that he is too much her son (a foreshadowing of the much more explicit attack in the closet scene, "you are the Queen, your husband's brother's wife. / But - would you were not so - you are my mother" (III.iv.15-16)). And, as numerous editors point out, the line carries the related lament that he is too much of a son-who-has-losta-father. As above, however, this "son/sun" is both matter and form: a thing and no thing, or a thing of nothing, as Hamlet later riddles (IV.ii.2628). As such, Hamlet's being "too much i'th'sun" refers not so much to himself as to Claudius. And thus begins the unnatural fracturing that characterizes the entire play: the sun/son homonym refers not to one person (as with Hal or Richard), but to two: the lines of reference, like those of succession in the play, are splintered. So too is the balance between matter and form; even before he meets the Ghost (whatever one thinks of his reference to his "prophetic soul" (I.v.41)), Hamlet seems very much of the opinion that his uncle is made up of considerably more matter than form. Claudius simply does not belong in Orbis Solis.

Whether he belongs there or not, however, the king's position is one that casts him, like the Ghost, as being both of the material world and beyond it. Hamlet's being "too much i'th'sun" serves, in this respect, as the opening gambit of his struggle to reconcile matter with form - to "accept physicality, with all its dissolute inconstancy, as the image of mentality" (Hunt 27), as John Hunt put it. The sun/son imagery offered here, then, takes a prominent place in a 
network of images across the play. These include not only those we noted earlier - the quintessence of dust, the reference to baser matter - but also in his (in)famous depiction of "the sun breed[ing] maggots in a dead dog" along with the invective to Polonius to keep Ophelia from "walk[ing] i'th'sun" (II.ii.182-185). These rhetorical solar images flash with the same vibrancy as Fludd's diagrams. We see in them a clear picture of the sun as being material and fleshy, particularly in terms of its ability to affect flesh by "breeding" either maggots or children in it; at the same time, the sun remains aloof and unearthly, especially as Hamlet's verbal images, are, after all, rhetorical and riddling, to be puzzled out in the mind.

Yet the theatre is, of course, a world of more than just the rhetorical image, and all of the above arises from and informs the encounter with the body on stage. The dualism I am tracing between matter and form is underscored - and, I venture to say, materialized - by the corresponding dualism of theatre, that most basic and fundamental "fact" about the actor's presence on stage: that (s)he is both actor and character at once. As Bert States said, this is "the inevitable starting point of any discussion of the actor's presence on the stage" $(1985,119)$. And while I did not actually start with this point, its saliency is hard to avoid now: the matter/form duality embedded in the image of the sun is perfectly realized in the actor/character duality embedded in the body on stage. Heninger's description of the Sun as having "a component to be perceived by the intellect which is exactly equivalent to its component to be perceived by the senses" (29) describes with equal accuracy the bodies we encounter on the stage, entities which, like the sun, seem to be composed of equal parts matter and form.
I began by suggesting that we consider the body on Shakespeare's stage as primarily matter and, indeed, as primary matter, and much of this consideration has involved looking at the body in terms of either prima materia or of the microcosm, both of which materialize that which cannot in fact be materially present (God, ideal form, the heavenly spheres, the sun). And therein lies the salience of this material perspective to the study of the Shakespearean body. Matter mattered, because it existed on a continuum with form; and where significant, primary, matter was present - as it was in the actor's body - the whole of that continuum was present, by virtue of the microcosmic-macrocosmic relationship. Keir Elam's chapter, which I used near the start of this article, frames the enquiry into the body in the "aftermath" of semiotics; though perhaps somewhat dated, it crystallizes the notion, still very current, that the body cannot merely be "read". As Elam suggests, however, once that semiotic limitation was registered, the body seemed to become (in the eyes of contemporary scholarship) many other things besides a text or a sign, but rarely, if ever did it fully become what it was: fleshy, heavy, unique matter.

To understand the body as such, and to look on the actor's body as a body-as-matter, particularly in light of other arenas of early modern visual culture, significantly colours our understanding of the actor's role in the theatremaking enterprise of Shakespearean England. That role is not simply the playing of a character, nor the presenting of signs about that character or the narrative in which he or she takes part. The role of the body involves the introduction of the most fundamental, elementary form of 
matter available to human experience to the theatrical experience. The actor's body serves as a pronouncement of material reality, called forth from a formal sphere of existence. Over and over again Shakespeare's stage-craft facilitates a turn from the image or the word to an irrefutably material presence: Macbeth's quick journey from an imagined dagger to the steel one he draws ("I see thee yet, in form as palpable / As this which now I draw" (II.ii39-40)); Bassanio's turn from the "likeness" of Portia in the casket to the living, breathing presence of the actor playing Portia ("Yet look how far / The substance of my praise doth wrong this shadow / In underprizing it, so far this shadow / Doth limp behind the substance" (III.ii126-129)); the shift from the portrait of Hamlet's father in the closet scene to the Ghost of his father, a move which, in a fashion rather different from Hal's, nonetheless seems to place us squarely in that "Orbis Solis," the sphere of perfect balance between form and matter (III.iv.94). These "material turns" are made possible by the material example set by the actor's body, and by the elementary function of that body; it is the body which serves as the first principle of materiality, and it is the body which contains, microcosmically and materially, all that the cosmos contains, enabling anything to be materially present in the theatre, indeed gathering other forms of matter to itself and to the stage. To turn the title of this essay, the verse from Luke, a little bit, we might conclude by saying "wheresoever the [actor's] body is, thether is the matter gathered together". 


\section{Works Cited}

Anon. The Key to Unknown Knowledge. London: Adam Islip, 1599.

Barlow, William. 'The Eagle and the Body'. Sermon, 1601. London: Matthew Law, 1609.

Callaghan, Dympna. 'Body Problems'. Shakespeare Studies 29 (2001), 68-71.

Crooke, Helkiah. Microcosmographia. London: 1615.

Digges, Leonard. A Prognostication Everlasting. London: 1576.

Elam, Keir. 'In What Chapter His Bosom?: Reading Shakespeare's Bodies.' Alternative Shakespeares, Vol 2. Ed. Terrence Hawkes. London: Routledge, 1996, 140-163.

Fludd, Robert. Utriusque Cosmi...Historia. Oppenheim, 1617.

Heninger, S.K. The Cosmographical Glass: Renaissance Diagrams of the Universe. The Huntington Library, 1977.

Hillman, David. Shakespeare's Entrails: Belief, Scepticism and the Interior of the Body. Houndmills, UK, and New York: Palgrave Macmillan, 2007.

Hunt, John. 'A Thing of Nothing: The Catastrophic Body in Hamlet'. Shakespeare Quarterly 39:1 (Spring, 1988), 27-44.

Maus, Katherine Eisaman. Inwardness and Theater in the English Renaissance. Chicago: The University of Chicago Press, 1995.

Owens, Margaret E. Stages of Dismemberment: The Fragmented Body in Late Medieval and Early Modern Drama. Newark: University of Delware Press, 2005.

Peacham, Henry. Minerva Britanna. London: 1612.

Rayner, Alice. 'Presenting Objects, Presenting Things.' Staging Philosophy: Intersections of Theater, Performance, and Philosophy. Eds. David Krasner and David Z. Saltz. Ann Arbor: University of Michigan Press, 2006, (180-199).

Rayner, Alice. Ghosts: Death's Double and the Phenomena of Theatre. Minneapolis: University of Minnesota Press, 2006.

Ruland, Martin. A Lexicon of Alchemy. Trans. A.E. White. London: 1892.

Rutter, Carol Chillington. Enter the Body: Women and Representation on Shakespeare's Stage. London and New York: Routledge, 2001.

Sanders, Eve Rachelle. 'The Body of the Actor in Coriolanus.' Shakespeare Quarterly 57:4 (Winter 2006): 387-412.

Saunders, Ben. Shakespeare's Entrails: Belief, Scepticism and the Interior of the Body. By David Hillman. Shakespeare Quarterly 59:1 (Spring 2008), pp 98-101 (Review).

Schoenfeldt, Michael C. Bodies and Selves in Early Modern England: Physiology and Inwardness in Spenser, Shakespeare, Herbert, and Milton. Cambridge: Cambridge University Press, 1999.

Shakespeare, William. The Norton Anthology. Ed. Stephen Greenblatt. New York: W.W. Norton and Company, 1997.

States, Bert 0. 'The Phenomenological Attitude'. In Critical Theory and Perfromance. Revised and Enlarged Edition. Ann Arbor: University of Michigan Press, 2007.

Thompson, Ann, and Taylor, N. eds. Hamlet The Arden Shakespeare. London: Methuen Drama, 2006.

Weimann, Robert. Author's Pen and Actor's Voice: Playing and Writing in Shakespeare's Theatre. Eds. Helen Higbee and William West. Cambridge: Cambridge University Press, 2000.

Woolton, John, Bishop of Exeter. A New Anatomie of whole man, as well of his body, as of his Soule. London: Thomas Purfoote, 1576.

Young, Alan, R. Ed. The English Emblem Tradition, Vol 5: Henry Peacham's Manuscript Emblem Books. Toronto: University of Toronto Press, 1998.

\footnotetext{
${ }^{1}$ By "Shakespearean body," I mean principally the actor's body on stage, as it is encountered in theatrical activity. That meaning, however, is of course contextualized by broader understandings of the human body and corporeality in Shakespearean England.

${ }^{2}$ David Hillman, Shakespeare's Entrails: Belief, Scepticism and the Interior of the Body (Houndmills, UK, and New York: Palgrave Macmillan, 2007); Michael C. Schoenfeldt, Bodies and Selves in Early Modern England: Physiology and Inwardness in Spenser, Shakespeare, Herbert, and Milton (Cambridge: Cambridge UP, 1999); Carol Chillington Rutter, Enter the Body: Women and Representation on Shakespeare's Stage (London and New York: Routledge, 2001); Margaret E. Owens, Stages of Dismemberment: The Fragmented Body in Late Medieval and Early Modern Drama (Newark: University of Delware Press, 2005); James R. Siemon, "Between the Lines: Bodies/Languages/Times", Shakespeare Studies 29 (2001): 36-43; Eve Rachelle Sanders, "The Body
} 
of the Actor in Coriolanus", Shakespeare Quarterly 57:4 (Winter 2006): 387-412. Indeed, Siemon's article takes part in an entire forum in Shakespeare Studies dedicated to the role of the body in Shakespearean criticism.

${ }^{3}$ Dympna Callaghan objects to this perspective, calling it "a sort of historicist idolatry [whereby] we have placed our faith in the thingness of things in order to avoid the messy interactions of matter and consciousness" (68). Her objection is levelled primarily (though not necessarily wholly) at the trend for analysing the body anatomically ("why", she asks, "should it be that we are all rushing to examine the multifarious meanings of early modern innards?" (69)). My position here, however, is that attentiveness to the body-as-matter is not an exercise in avoiding the complicated relationship(s) between matter and consciousness, but quite the contrary, it is a very apt avenue for exploring those relationships. See Dympna Callaghan, "Body Problems," in Shakespeare Studies 29 (2001): 68-71.

${ }^{4}$ There are, naturally, important exceptions to this trend, both within and outside of the broad field of Shakespearean or early modern studies. One thinks most readily, of course, of Judith Butler's troubling of the relationship between bodies and selves, and of the vast amount of body-subject scholarship that has been built upon her work. Closer to home, with respect to Shakespearean studies, Katherine Maus' influential work on inwardness and theatre offers a detailed study of the relationship between concepts of inner truth(s) and external shows.

${ }^{5}$ Of even greater relevance here than Butler or Maus might be more sustained studies of embodiment, such as those which dominated the thinking and career of Maurice Merleau-Ponty.

${ }^{6}$ Alice Rayner has suggested (without recourse to alchemical terminology) something similar for role of props: "Stage props", Rayner claims, "as paradigmatic objects, constitute the worldliness of the stage and in a sense are owned by the stage; properties in all senses, they give their material attributes to an otherwise empty space and in turn populate that space, dominate it, 'own' it" (181). While I agree with the overall tenor of her argument, it strikes me that the same can, and should, be said for the body, and probably in even greater measure.

${ }^{7}$ The process, of course, is not quite so simple. Indeed, what I propose here is one segment of a larger thesis, which suggests that such 'bodying forth' (a phrase borrowed from Theseus in A Midsummer Night's Dream) is a product of the combined labours of the body and the word on stage, particularly when the words are counted - as in great measure they were - as material entities in their own right. I am detailing this larger thesis elsewhere; for this current article, however, I wish to focus specifically on how we might see the materiality of the body more clearly and more critically.

${ }^{8}$ Indeed, this line of thought was current not only in alchemy and cosmography, but medicine and anatomy more broadly. Helkiah Crooke's 1615 medical treatise, for example, is actually entitled Microcosmographia: $A$ Description of the Body of Man [...]. In his introduction to the first chapter (on anatomy), Crooke begins by citing classical thinkers and physicians who speak of Man -- in body and soul - as a microcosm:

That thrice-worthy Mercury calls him a great Myracle, a Creature like the Creator, the Ambassador of the Gods. Pythagoras [calls Man] the Measure of all things. Plato [calls Man] the wonder of Wonders. Theophrastus, the patterne of the whole universre. Aristotle, a politicke creature framed for society. Synesius, the Horizon of Corporeal and Incorporeal things. Tully, a divine creature, full of reason and judgment. Pliny, the World's epitome and Natures Darling. Finally, all men with one consent, call him , [Microcosmos], or The little world. For his bodie, as it were, a Magazine or StoreHouse of all the vertues and efficacies of all bodies, and in his soule is the power and force of all living and sensible things (3).

${ }^{9}$ Young's translation of the epigram for this image is: "Endowed with the sparks of the divine mind from on high / Am I mistaken that the realm of heavenly Jove has created them? / And of harmonious design in which you may count so many marvels / Of the beautiful universe - this is man, the microcosm."

${ }^{10}$ Indeed, Peacham's second emblem can also be found in Heninger's seminal work, the Cosmographical Glass, wherein he dedicates a chapter to the subject of the human microcosm. In much of that chapter, he focuses on "the human condition as a microcosm of day and night" (150, 152-153), and vice versa.

${ }^{11}$ See, for example, The Key to Unknown Knowledge, an anonymous medical treatise dating from 1599 which stipulates that 'Princinpally it is to bee understood, that in mans bodie bee foure natural vertues (to wit) the vertue of Attraction, the vertue of Retention, the vertue of Digestion, and the vertue of Expulsion. The vertue of Attraction worketh with hot and drie, therefore the medicine most answerable to be received for that kind, ought to bee ministered when [the moon] is in a signe hot and drie, as [Aries, Leo, Saggotario] having then no impediment' ('Judicial Rules of Physick'; accessed on EEBO, 5 February, 2012: 
http://eebo.chadwyck.com/search/full rec?SOURCE=pgimages.cfg\&ACTION=ByID\&ID=99843650\&FILE=../sessi on/1328555008 18734\&SEARCHSCREEN=CITATIONS\&VID=8396\&PAGENO=5\&ZOOM=FIT\&VIEWPORT=\&SEAR CHCONFIG=var spell.cfg\&DISPLAY=AUTHOR\&HIGHLIGHT KEYWORD=)

${ }^{12}$ All three of these diagrams appear in Heninger, and I am grateful to his book, as it has clearly provided a wealth of imagery for this article, and drawn my attention to other sources his book does not include.

${ }^{13}$ John Hunt, in fact, made such an argument quite convincingly nearly 25 years ago; Hunt suggested then that "[n]ot until [Hamlet] finds his way out of a despairing contempt for the body can he achieve the wish of his first soliloquy and quietly cease to be". See "A Thing of Nothing: The Catastrophic Body in Hamlet", Shakespeare Quarterly 39:1 (Spring 1988), 27-44, esp 27.

${ }^{14}$ A Midsummer Night's Dream, V.i.16. Theseus' description of the labours of the poet offers an excellent way of thinking about the relationship between material and immaterial realities:

The poet's eye, in a fine frenzy rolling,

Doth glance from heaven to earth, from earth to heaven

And as imagination bodies forth

The forms of things unknown, the poet's pen

Turns them into shapes, and gives to airy nothing

A local habitation and a name.

(V.i.12-17)

${ }^{15}$ Weimann distinguishes "between the locus as a fairly specific imaginary locale or self-contained space in the world of the play and the platea as an opening in mise-en-scéne through which the place and time of the stage-as-stage and the cultural occasion itself are made either to assist or resist the socially and verbally elevated, spatially and temporally remote representation" (181). See Author's Pen and Actor's Voice: Playing and Writing in Shakespeare's Theatre. Eds. Helen Higbee and William West. (Cambridge: Cambridge UP, 2000). Hamlet's speech brings into view for the audience both the 'locus' of Elsinore and the 'platea' of the Globe stage, the here and now.

${ }^{16}$ Hamlet's line, as cited here, uses "sun" as the base word for the pun, but it is worth noting that Q2 has the line as "in the sonne" and the Arden editors use "in the 'son'". 